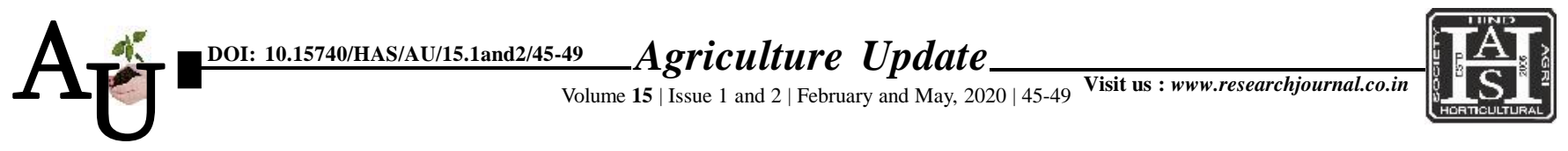

ISSN-0973-1520

\title{
Research Article: Technological gaps in major vegetable crops and suggestions to sustain the vegetable production
}

\section{A. Janaki Rani}

Article Chronicle:

Received :

19.02.2020;

Revised :

03.04.2020;

Accepted :

11.04.2020

\section{Key Words :}

Vegetable growers, Technology gap, Technology index, Production, Productivity
SUMMARY : Vegetables provide smallholder farmers with much higher income and more employment than staple crops. Even though vegetable area is higher in India, the farmers who produce vegetable crops, struggle a lot to bring them up. A wide gap exists between the yields obtained and the potential yields due to non-adoption of scientific technologies. Keeping this in view the study was conducted with 90 vegetable growers in Madurai district of Tamil Nadu, India to assess the real technological gaps and yield gaps. The results showed that the major yield gap is due to increasing intensity of pest and diseases and physiological disorders due to climate change viz., fruit borer $(70.00 \%)$, blossom dropping and less fruit setting percentage $(68.33 \%)$, sunscald due to high temperature $(61.66 \%)$, fruit cracking $(53.33 \%)$, deformation of fruit and lower quality $(51.66 \%)$, yellow or green fruit shoulders $(46.66 \%)$ and okra curling/small size of fruit and hardness of fruit $(40.00 \%)$. The major technological gaps are due to non-application of foliar spray / micronutrient spray /growth regulators $(100.00 \%)$, non-adoption of IPM packages (77.77\%), seed treatment practices with biofertilizers and bio agents (56.66\%), application of recommended quantity of top dressing (63.33) and mulching (50.00\%). Improved package of practices can decrease the technology gap; thereby productivity of the crop can be increased.Training programme on improved vegetable production technology along with multiple demonstrations is required to enhance level of knowledge and skills which increase the yield and income.

How to cite this article : Rani, A. Janaki (2020). Technological gaps in major vegetable crops and suggestions to sustain the vegetable production. Agric. Update, 15(1 and 2): 45-49; DOI : 10.15740/HAS/AU/15.1and2/45-49. Copyright@2020: Hind Agri-Horticultural Society.
Author for correspondence :

\section{A. Janaki Rani} Department of Human Development and Family Studies, Community Science College and Resarch Institute (T.N.A.U.), Madurai (T.N.) India

Email : janakimurugan8@ gmail.com 